Ks. Jan Witold Żelazny ${ }^{1}$

\title{
Cyprian u Tymoteusza. Odwołania do decyzji synodalnych Cypriana z Kartaginy w polemice w Kościele Orientalnym w VIII wieku
}

\section{Tymoteusz I i jego czasy}

Tymoteusz I był patriarchą Asyryjskiego Kościoła Wschodu w latach 780-823. Jego wybór przebiegał w atmosferze skandalu i oskarżeń o symonię. Plotka głosiła, że rozmawiając z elektorami, miał przy sobie sakiewki z pieniędzmi. Po wyborze, kiedy to część wyborców spodziewała się nagrody, miał ze zdziwieniem zauważyć: chcieliście sprzedać Jezusa? Czy ta opowieść jest prawdziwa, nie wiadomo, ale bez wątpienia w pierwszych latach rządów Tymoteusz napotkał na zdecydowaną opozycję ${ }^{2}$. Sprawę komplikowały napięcia związane z przenikaniem się tradycji różnych kultur. W spadku po Imperium Perskim ciągle pojawiały się kwestie związane $\mathrm{z}$ małżeństwami pomiędzy bliskimi krewnymi ${ }^{3}$. Zachowane ustawodawstwo Tymoteusza I w tej kwestii ${ }^{4}$, a raczej kompilacja wcześniejszych orzeczeń dotyczących w większości tego zagadnie-

1 Ks. dr hab. Jan Witold Żelazny, pracownik Katedry Patrologii Wydziału Teologicznego Uniwersytetu Papieskiego Jana Pawła II; e-mail: atzelazn@cyf-kr.edu.pl; ORCID: 0000-0003-3653-0639.

2 Sama elekcja, zachowane źródła, jak i przytoczona historia są krytycznie przeanalizowane w pracy V. Bertiego (Vita e studi di Timoteo I Patriarca cristiano di Baghdad, Studia Iranica. Cahier 41, Paris 2009, s. 152-157).

3 Patrz problem powstania arystokracji chrześcijańskiej na tym tle: R.P. Payne, State of mixture, Oakland 2015, s. 127-129.

4 O. Braun, Zwei Synoden des Katholikos Timotheos I, „Oriens Christianus” 2 (1902) s. 283-311. 
nia jest tego dowodem 5 . Było to podwójnie groźne dla niego i Kościoła, którym kierował - z jednej strony rosnąca presja islamu, $\mathrm{z}$ drugiej podziały wśród chrześcijan skutkujące „wędrowaniem” od konfesji do konfesji. Zagadnienie ewentualnego powtórnego chrztu dla wiernych przychodzących ze wspólnot melkitów czy też sewerian było realne i istotne. Mnożenie trudności mogło spowodować odpływ wiernych w jedną stronę. Sprawa budziła więc kontrowersje.

Nie znamy całej korespondencji. Dwa zachowane listy, które dotyczą tego zagadnienia, pozwalają jednak na stwierdzenie wagi problemu, jak i dyskusji, jaką budził przepływ wiernych z jednej wspólnoty do drugiej. Był on problematyczny dla wielu, stąd powstała sama kontrowersja na łonie Asyryjskiego Kościoła Wschodu dotycząca powtórnego chrztu chrześcijan pochodzących z innych Kościołów.

W zachowanym liście widać ślady tych napięć. Ma on bowiem dwa dodane fragmenty. Jeden $z$ nich ma być podsumowaniem decyzji patriarchy, choć w treści raczej wygląda na zredagowany przez kogoś pozostającego w łączności z patriarchą, ale nie za bardzo przekonanego do otwarcia drzwi. Kolejny fragment to ryt pojednania grzesznika z Kościołem.

$\mathrm{Na}$ tym tle pojawia się odwołanie jednego z prowadzących polemikę, Salomona Biskupa Hedatty, do decyzji Cypriana, biskupa Kartaginy, jako autorytetu uzasadniającego konieczność powtórnego chrztu dla chrześcijan przyjmujących ten sakrament we wspólnotach niepozostających w łączności z Patriarchą Seleucji - Ktezyfonu (Bagdadu) ${ }^{6}$, a pragnących włączyć się do wspólnoty Kościoła Orientalnego. W opublikowanym przez J.B. Chabot Synodikon Orientale nie ma ani jednego odwołania do Cypriana i orzeczeń z Kartaginy. Rodzą się pytania dotyczące zarówno znajomości orzeczeń z Kartaginy w ówczesnym Kościele Orientalnym, kontekstu ich uchwalenia, jak i poczucia jedności wspólnoty wierzących niezależnie od miejsca i czasu powstałych rozwiązań. Przedłożenie jest próbą odpowiedzi na te pytania.

\section{Spór z Salomonem, biskupem Hedatty}

W dwóch swoich listach Tymoteusz podejmuje dyskusję związaną z kwestią powtórnego chrztu w przypadku przyjmowania do Kościoła

$5 \quad$ Syrische Rechtsbücher. Zweiter Band: Richterliche Urteile des Patriarchen Chenânîschô. Gesetzbuch des Patriarchen Timotheos. Gesetsbuch des Patriarchen Jesubarnun, t. 2, ed. E. Sachau, Berlin 1908 (wstęp: s. XVII-XXI, spis Kanonów s. XXVIIXXIX, tekst s. 53-117).

6 List powstaje w czasie, gdy dokonano przeniesienia stolicy do Bagdadu. 
wiernych $\mathrm{z}$ innych wspólnot chrześcijańskich. Kontrowersja była związana z wracającymi do wspólnoty Kościoła Asyryjskiego wiernymi ochrzczonymi przez sewerian. Salomon odwoływał się do tradycji Kościoła negującej chrzest nieudzielony w imię Trójcy Świętej i uważał, że wiernych wracających z monofizytyzmu należy ponownie chrzcić. Skoro ich nauka o Trójcy jest nieortodoksyjna, to zdaniem Biskupa Hedatty i chrzest nie jest ważny.

Ostrze polemiki dotyczyło więc kwestii wiary. W swoim liście Tymoteusz rozwija koncepcję rozróżnienia wiary i wyznania wiary jako dwóch różnych elementów. Wiara, fundamentalna dla zbawienia, nie zamyka się w formułach, które jedne lepiej, inne gorzej próbują wyrazić to, co jest niewyrażalne. Istotą chrześcijaństwa jest wiara $\mathrm{w}$ Boga Stworzyciela, w Jego Syna będącego Bogiem i człowiekiem i w Ducha Pocieszyciela. Kwestie tego, jak dokonało się spotkanie bóstwa i człowieczeństwa w Chrystusie, czy jest to zlanie, jak u monofizytów, czy unia natur, czy zjednoczenie osób jest już drugorzędne. Tymoteusz pisze:

Spór nasz z nimi i ich z nami nie jest co do chrztu ani też co do bóstwa, które w Trójcy, ani też co do Trójcy, która w bóstwie, ani znowu co do bóstwa i człowieczeństwa Pana naszego Chrystusa, ale co do zjednoczenia $^{7}$ bóstwa i człowieczeństwa jaki cierpienia i śmierci, które naturalnie weszły do bóstwa. Tak odrzucamy te (twierdzenia), poprawiamy i ukazujemy błędność. Dlatego nie [jest] słusznym dla nas, że będą przeklinani za wyznanie i za pojedynczość bóstwa i Trójcy, i za adorację i wyznanie zmartwychwstania z martwych, i za wyznanie bóstwa i człowieczeństwa Pana naszego i nie za pojedynczość osoby synostwa naturalnego i panowania ${ }^{8}$. Pięknym więc, że wszystko to wyznają jak my i z nami. Dlatego nie jest słusznym, że ganimy ich z powodu chrztu tego, który w imię Ojca i Syna, i Ducha Świętego się wypełnia, pięknie, jak my i z nami, [tak samo i oni] wypełniają.

Dlatego chrzest udzielany przez sewerian i melchitów jest ważny, choć nie jest godny. ,Jest to złoto, choć pobrudzone, żelazo, choć zardzewiałe”, istota pozostaje jednak ta sama. Skoro istota pozostaje ta sama, ochrzczeni w tych wspólnotach są chrześcijanami.

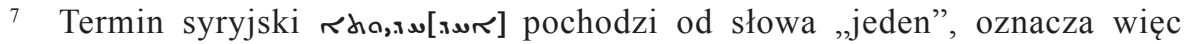
coś, co samo staje się jednością pełną, a co nie do końca jest obecne w terminie „zjednoczenie/unia”.

Dosł. 'bycie panem'.

9 Por. Tymoteusz, List I 76-77 


\section{Cyprian i synod w Kartaginie w argumentacji dotyczącej powtórnego chrztu}

Nie znamy listu Salomona. W swojej argumentacji, jak się wydaje, odwołał się między innymi do postanowień Klemensa Rzymskiego, Cypriana z Kartaginy i synodu w Laodycei. Tak pisze o tym Tymoteusz: „Rozpoznaję słowa Twoje, o pełny mądrości, i rozumiem i czasy oraz rzeczy w tych czasach uczynione! Ani więc sewerian, ani melkitów wtedy nie było; ani za dni Klemensa rzymskiego, ani za dni Cypriana Afrykańskiego, ani też na zebraniu synodalnym, które było w Laodycei [...]"10. Z tymi bowiem wymienionymi postanowieniami prawnymi podejmuje dyskusję patriarcha w swojej odpowiedzi.

W pierwszym przypadku chodzi prawdopodobnie o Kanony apostol$s_{k i e}{ }^{11}$. Wiemy, że kolekcja pism przypisywana Klemensowi Rzymskiemu, w skład której wchodzi przywołana kolekcja prawna, cieszyła się dużym autorytetem wśród chrześcijan orientalnych. W rzeczywistości Tymoteusz nie przywołuje konkretnego przepisu. W zachowanej greckiej wersji kanonów w punkcie 46 czytamy ${ }^{12}$ : „Biskupa lub prezbitera, którzy uznają chrzest lub ofiarę heretyków, nakazujemy złożyć z urzędu. Jakaż jest bowiem wspólnota Chrystusa z Belialem? Albo wierzącego z niewierzącym?"'13. Jeszcze wyraźniejszy i bardziej precyzyjny jest kanon 50. Przytoczmy w całości interesujący nas fragment:

Kandydata do chrztu trzeba pouczyć, że Ojciec nie został ukrzyżowany, ani nie urodził się jako człowiek, [bo nie mając nad sobą władcy nie podlegał niczyjej woli ani decyzji]; że Duch Święty nie stał się człowiekiem [nie przyszedł na świat], nie doznał męki [nie mając ciała], ponieważ nie został wcielony. Od nadchodzącego gniewu ocalił świat [sam] jednorodzony Syn, który z miłości do ludzi stał się człowiekiem, ukształtowawszy sobie ciało w łonie dziewicy: „Mądrość bowiem zbudowała sobie dom” (Prz 9,1) jako Stwórca. Syn dobrowolnie przyjął krzyż [za zgodą Ojca] i wybawił świat

10 Tymoteusz, List 1, do Salomona, biskupa Hedatty, w: Tymoteusz I, Listy, Kraków 2015, s. 80 .

11 Kanony apostolskie zostały dołączone do tak zwanych Konstytucji apostolskich i zachowały się wraz z nimi. Po orzeczeniu podczas synodu in Trullo (691/692) o nieapostolskości samych Konstytucji uznano jednak ich pochodzenie i odtąd przepisywano je niezależnie od samych Konstytucji.

12 Constitutiones Apostolorum, tł. S. Kalinkowski, ŹMT 42, Kraków 2007, s. $283-283 *$.

132 Kor 6,15 . 
od nadchodzącego gniewu [jako Arcykapłan] (Heb 9,11). Otrzymujemy więc chrzest: w imię Ojca, który nie stał się człowiekiem i nie poniósł męki, [bo nie jest On niczyim Arcykapłanem, lecz jest niezależnym Władcą, który dopuścił narodzenie oraz zgodził się na mękę, którą przyjął za pośrednictwem Arcykapłana]; w imię Syna [który nie jest niezależnym Władcą, nie dopuścił się i nie zgodził], lecz się narodził, poniósł mękę na krzyżu, umarł i zmartwychwstał; [w imię Parakleta, który nie jest Ojcem ani Synem, lecz świadczy o dobroci Ojca oraz o zgodzie i całkowitym posłuszeństwie Jednorodzonego]. Tych, którzy udzielają chrztu niezgodnie z tymi zasadami, należy złożyć z urzędu, ponieważ nie znają tajemnicy wiary ${ }^{14}$.

Rozbudowana wypowiedź, abstrahując od jej wydźwięku dogmatycznego, wpisuje się w tok odpowiedzi Tymoteusza, który stwierdza, że ani sewerianie, ani melkici nie mówią nic sprzecznego z tym ogólnym wyznaniem, a różnią się tylko rozumieniem zjednoczenia ${ }^{15}$.

Interesujące nas dowodzenie dotyczy argumentacji $\mathrm{z}$ kanonów Cypriana. My znamy decyzje synodu (synodów) w Kartaginie w sprawie chrztu heretyków z listów Cypriana ${ }^{16}$. W przypadku Tymoteusza jednak, $\mathrm{z}$ uwagi na dodane zakończenie listu, wynika, że mowa była o tzw. kanonie 20. O który kanon chodzi i z którego zebrania biskupów? Nie mamy precyzyjnych danych. $Z$ tekstu odpowiedzi Tymoteusza wynika, że prawdopodobnie przedmiotem polemiki pomiędzy nim a biskupem Hedatty stał się kończący synod w Kartaginie z 1 września 256 roku kanon, który wersji łacińskiej brzmi następująco:

Cyprian z Kartaginy rzekł: Moje zdanie wyraża najpełniej list, pisany do kolegi Jubajana, że heretyków, nazwanych według ewangelicznego i apostolskiego świadectwa przeciwnikami Chrystusa i antychrystami, gdy wracają do Kościoła, należy chrzcić jednym chrztem Kościoła, by mogli z przeciwników stać się przyjaciółmi, a z antychrystów - chrześcijanami ${ }^{17}$.

14 Constitutiones Apostolorum, s. 284-285*. W nawiasach kwadratowych dodane uzupełnienia z rekonstrukcji tekstu E. Schwartza i C.H. Tunera obecne w edycji Metzgera w SC (za przypisem B 284*).

15 Patrz: „Ich schizma nie jest co do bóstwa i człowieczeństwa, bardziej co do zjednoczenia bóstwa i człowieczeństwa. I kłó cą się nie co do substancji czy natury, ale co do jakości i właściwości zjednoczenia”. Tymoteusz, List I 72.

16 Tekst polski i łaciński w: Acta synodalia ann. 50-381, red. A. Baron - H.Pietras, ŹMT 37, Kraków 2006: Kartagina 255 (Cyprian, List 70), s. 21-24*; Kartagina wiosna 256 (Cyprian, List 72), s. 25-27*; Kartagina 256, 1 września (Orzeczenie 87 biskupów o chrzcie heretyków), s. 27-41*.

17 Acta synodalia ann. 50-381, s. 41*. 
Wydaje się, że odpowiedź Katolikosa dotyczy tej decyzji. Pisze on:

Ani więc sewerian, ani melkitów wtedy nie było. Ani za dni Klemensa rzymskiego, ani za dni Cypriana afrykańskiego, ani też na zebraniu synodalnym, które (było) w Laodycei nie było ani jednej z tych idei i zwyczajów heretyckich i herezji. Ci heretycy więc, liczni oni, ani nie byli ochrzczeni w imię Trójcy, inni zaś byli ochrzczeni nie w imię Trójcy współnaturalnej i wspólistotnej, ale w [imię Trójcy] niewspółistotnej i niewspółnaturalnej; inni zaś w imię puste Trójcy, tej, która nie jest w trzech osobach - w jednej osobie mówili, że jest [Trójca]; inni znowu zupełnie zgodnie z opinią żydowską, Trójcę odrzucili i w Chrystusa człowieka zwyczajnego wierzyli. Inni, w opozycji do nich, Chrystusa jedynie Bogiem nazywali, jak poprzednio zostało powiedziane, kiedy Pisma skazili i zmieszali. I co do nich i im podobnych heretyków pierwsi Ojcowie nie niesłusznie postanowili, że nie będą przyjęci do Kościoła bez obmycia, które [jest] w ochrzczeniu. Albo bowiem całkowicie nie byli ochrzczeni, albo jedynie w puste i bezowocne imię ${ }^{18}$.

Ciężar jego rozumowania opiera się na jednym. Rozstrzygnięcie przyjęte w Kartaginie, czy przekazane przez Klemensa, dotyczyło innych heretyków. Nie można więc aplikować tych rozstrzygnięć dowolnie, ale należy odnieść je do kontekstu. Jeśli wiara jest ta sama, jeśli tym, co nas różni, jest tylko jej sformułowanie, to nawet mając rację co do sformułowań, nie wolno negować wartości sakramentów udzielanych przez drugiego współbrata.

Kontynuując swoje dowodzenie, odwołuje się Katolikos do soboru nicejskiego. Przypomina on, że orzeczenia synodów 318 i 150 ojców (Nicea i Konstantynopol) są fundamentem wiary, zarówno dla niego, jak i dla Salomona. Tymczasem w kanonie 8 tego soboru ${ }^{19}$ wyraźnie stwierdzono, że nowacjan przyjmuje się do Kościoła bez powtórnego chrztu.

18 Tymoteusz I, Listy I-VIII, tł. Jan Żelazny, Kraków 2015, s. 80.

19 Kan. VIII: „O tych, którzy zwą się «czystymi». W sprawie tych, którzy nazywają samych siebie "katharoi», czyli czystymi, święty i wielki sobór postanowił, że jeśli chcą powrócić do powszechnego i apostolskiego Kościoła, muszą otrzymać nałożenie rąk, a będą mogli pozostać w gronie duchownych. Konieczne jest jednak, przede wszystkim, aby oni przyobiecali na piśmie, że zgadzają się i będą posłuszni nauczaniu Kościoła powszechnego [...]". Dokumenty soborów powszechnych, tekst grecki, taciński i polski, t. 1, opr. A. Baron - H. Pietras, ŹMT 24, Kraków 2001, s. 32-35. Tekst syryjski ani treścią, ani numeracją nie odbiega od greckiego, stąd przyjmuję przyjęte już tłumaczenie na język polski. Patrz: Die syrischen Kanones der Synoden von Nicaea bis Chalcedon, red. F. Schulthess, Berlin 1908, 88-89. 
Podobną decyzję jego zdaniem podjął przywoływany przez Salomona synod w Laodycei ${ }^{20}$, który w kanonie 7 miał zadekretować:

[...] co do tych, którzy są z herezji fotynian i nowacjan,ci kwartodecymian, że będą przyjęci do stanu Kościoła katolickiego nie przez chrzest, ale przez ekskomunikę przywódców ich herezji i także wszystkich innych herezji, po nauczeniu symbolu wiary i po oleju namaszczenia, którym są namaszczani. W kanonie zaś 8 , co do tych, którzy z herezji Frygijczyków byli, i znaczniejszych i małych, jako tych, którzy zbłądzili i w teologii, jak i w racji uczłowieczenia, zadecydowali, że nie jedynie przez modlitwę i przez pojednanie, [ale że] w tym wypadku przez chrzest pełny będą przyjęci ${ }^{21}$.

Zdaniem patriarchy decyzja co do powtórnego chrztu zależy od nauki o Trójcy, a nie od samego faktu bycia heretykiem. Jest więc to rozstrzygnięcie w duchu decyzji papieży i synodów, gdzie raczej wystrzegano się podejmowania rozwiązań jednakowych dla wszystkich, mając świadomość różnic pomiędzy wspólnotami. Zresztą, dla badaczy nie ulega wątpliwości, że pojawiające się na tym tle kontrowersje często były spowodowane inną konotacją słowa „heretyk”, które na przykład dla mieszkańca Afryki za czasów Cypriana odnosiło się do gnostyków czy montanistów podejrzewanych o błędną naukę o Duchu Świętym, a w tym samym czasie w Rzymie było synonimem nowacjan różniących się od pozostałych wiernych kwestiami dyscyplinarnymi.

\section{Znajomość Afryki i jej teologii przez chrześcijan Orientu}

Trzeba wyraźnie powiedzieć, że znajomość chrześcijan afrykańskich na obszarze chrześcijańskiego Orientu nie była duża. Fakt cytowania i zna-

20 Laodycea (IV wiek): „Ci, którzy nawracają się z herezji, mianowicie z herezji nowacjan, fotynian i kwartodecymianów, niezależnie od tego, czy byli tam katechumenami czy wiernymi, nie mogą być przyjęci, zanim nie potępią wszystkich herezji a zwłaszcza tej, którą wyznawali. Ci, którzy w sekcie nosili tytuł wiernych, mogą brać udział w świętych obrzędach dopiero wówczas, gdy nauczą się wyznania wiary i otrzymają namaszczenie świętym olejem. [...] Ci, którzy nawracają się z herezji zwanej «katafrygijską» choćby należeli tam do rzekomych duchownych, choćby nosili tam tytuł "wiernych», winni odbyć szczególnie dokładną katechezę u biskupów i prezbiterów Kościoła oraz przyjąć chrzest”" Acta synodalia ann. 381-431, red. A. Baron - H. Pietras, ŹMT 52, Kraków 2010, s. 111*_ 112*. Tekst grecki: Acta synodalia ann. 381-431, s. 111-112, tekst syryjski: Die syrischen Kanones der Synoden von Nicaea bis Chalcedon, s. 88-89.

21 Tymoteusz, List I 81. 
jomości rozstrzygnięć Cypriana z Kartaginy nie jest czymś nadzwyczajnym. Wiemy, że w tym czasie sporządzono niejedną kompilację tekstów prawnych Kościoła dla potrzeb Orientu. Najstarsze dokumenty tego typu w kręgu języka syryjskiego, jak Octateuch Klementyński czy Didaskalia, czy też wspomniane wcześniej, choć późniejsze, zawierające Didaskalia dzieło Konstytucje apostolskie jako kompilacje tekstów prawnych chętnie odwoływały się do krążących tekstów łacińskich. Znajomość Cypriana mogła więc być nie tyle znajomością samego Cypriana, co zapoznaniem się $\mathrm{z}$ jedną $\mathrm{z}$ takich kolekcji. Jeśli chodzi o teksty greckie używane przez Tymoteusza (Atanazego, Grzegorza z Nazjanzu czy innych wielkich ojców greckich IV i V wieku), mamy pewność, że Katolikos znał je i w tłumaczeniu, i w oryginale. W tym przypadku tej pewności nie mamy, a raczej należy wątpić $\mathrm{w}$ taką ewentualność.

Tym niemniej z listu wynika jedno. Zarówno dla Salomona, jak i dla Tymoteusza nie ulega wątpliwości, że dziedzictwo synodów kartagińskich, synodów odbywających się daleko od nich, 500 lat wcześniej, to ich dziedzictwo. To tak, jakby dzisiejsi mieszkańcy Polski za swoje uznawali postanowienia unii lubelskiej czy konfederacji warszawskiej. Jeden i drugi odwoływali się do tych dokumentów i pism, jeden i drugi za swego „ojca w wierze" uważali biskupa Afryki Prokonsularnej. Dla jednego i drugiego dziedzictwo chrześcijańskiej Afryki było ich dziedzictwem. Innymi słowy, obaj czuli się częścią jednego Kościoła. Ich problemy, ich dyskusje miały miejsce $\mathrm{w}$ innym czasie, $\mathrm{w}$ innych warunkach, a mimo wszystko czuli oni ciągłość. Dlatego zachowana korespondencja patriarchy Orientu jest ciekawym przyczynkiem do rozważań na temat teologii afrykańskiej i jej wpływu na cały Kościół, w tym także Kościół orientalny.

\section{Cyprian at Timothy I. Appeals to the Decision of the Synod of Cyprian of Carthage in Controversy in the Oriental Church in the Eighth Century}

(summary)

The analyzed texts, taken from the Letters of Timothy I, the patriarch of Baghdad, concerning his dispute with Solomon, the Bishop of Hedegaard, for the recognition of the validity of the baptism given in the communities not connected with the Assyrian Church of the East (Severians and Melkites, that is, in older terminology, monophysicists and orthodox), do not give grounds to talk about the close contacts of Oriental Christians with Christians in Africa. Knowledge of the controversies faced by Africans and the writings written in this context in pro-consular Africa in the Middle East and the Middle East does not give grounds to formulate the categorical judgments. It is a fact that there is a reference to the judgments of the Carthage Adversaries. However, the quotations presented here may well come from the le- 
gal collections where the decisions of synods were collected without going into the context of their origin, often mixing the canons. This kind of collection was widespread at that time and we know that both Timothy and Salamon had access to it. The preserved Syrian collections from that period do not mention the analyzed decisions. One thing is certain: for the two discussants, Timothy and Solomon, living in Mesopotamia in the 8th century, the legacy of the 3rd century African synods is their legacy, and the decisions made there are binding upon them. Whether they appeal to the real decisions, or whether they only think so, may remain a matter of discussion. However, the awareness of common tradition and communication is the axiom in the dispute and the axiom of the argumentation used.

Keywords: Timoty I; Cyprian; synod of Carthage; synod of Laodicea; baptism

\title{
Cyprian u Tymoteusza. Odwołania do decyzji synodalnych Cypriana z Kartaginy w polemice w Kościele Orientalnym w VIII wieku
}

\author{
(streszczenie)
}

Analizowane teksty zaczerpnięte z Listów Tymoteusza I, patriarchy Bagdadu dotyczące jego sporu z Salomonem, biskupem Hedaty, o uznanie ważności chrztu udzielonego we wspólnotach niepozostających w łączności z Asyryjskim Kościołem Wschodu (sewerianie i melkici w starszej terminologii to monofizyci i ortodoksi), nie dają podstaw do mówienia o bliskich kontaktach chrześcijan orientalnych z chrześcijanami w Afryce. Znajomość kontrowersji, z którymi borykali się Afrykańczycy, jak i pism powstałych w tym kontekście w Afryce Prokonsularnej na Bliskim i Środkowym Wschodzie też nie dają podstaw do formułowania kategorycznych sądów. Jest faktem odwołanie do orzeczeń pochodzących zdaniem adwersarzy z Kartaginy. Prezentowane cytaty mogą jednak równie dobrze pochodzić z kolekcji prawnych, w których zbierano orzeczenia synodów bez wnikania w kontekst ich powstania, często mieszając kanony. Ten rodzaj zbiorów był rozpowszechniony w tym czasie i wiemy, że obaj, Tymoteusz i Salomon, mieli do nich dostęp. Zachowane kolekcje syryjskie z tego okresu nie mówią o analizowanych rozstrzygnięciach. Jedno jest pewne, dla obu dyskutantów, Tymoteusza i Salomona, mieszkających na terenie Mezopotamii w VIII wieku dziedzictwo synodów afrykańskich z III wieku jest dla nich ważne, a podjęte tam rozstrzygnięcia ich obowiązują. Czy odwołują się do rzeczywistych decyzji czy tylko tak uważają, może pozostawać kwestią dyskusji. Jednak świadomość wspólnej tradycji i łączności jest aksjomatem w toczonym sporze, jak i aksjomatem używanej argumentacji.

Słowa kluczowe: Tymoteusz I; Cyprian; synod w Kartaginie; synod w Laodycei; chrzest

\section{Bibliografia}

\section{Źródla}

Acta synodalia ann. 50-381, red. A. Baron - H. Pietras, ŹMT 37, Kraków 2006. Acta synodalia ann. 381-431, red. A. Baron - H. Pietras, ŹMT 52, Kraków 2010. 
Constitutiones Apostolorum, SC 320, 329, 336, ed. M. Metzger, tł. S. Kalinkowski, ŹMT 42, Kraków 2007.

Dokumenty soborów powszechnych, tekst grecki, łaciński i polski, t. 1, opr. A. Baron H. Pietras, ŹMT 24, Kraków 2001.

Syrische Rechtsbücher. Zweiter Band: Richterliche Urteile des Patriarchen Chenânîschô.

Gesetzbuch des Patriarchen Timotheos. Gesetsbuch des Patriarchen Jesubarnun, t. 2-3, ed. Sachau, Berlin 1908.

Schulthess F., Die syrischen Kanones der Synoden von Nicaea bis Chalcedon nebest einigen zugehorigen Dokumenten, Berlin 1908.

Timothei Patriarchae I, Epistulae, ed. O. Braun, CSCO 74, Parisiis 1914.

Timothei Patriarchae I, Epistulae, int. O. Braun, CSCO 75, Romae - Paris 1915.

Tymoteusz I, Listy I-VIII, tł. J. Żelazny, Kraków 2015.

\section{Opracowania}

Berti V., Vita e studi di Timoteo I Patriarca cristiano di Baghdad, Studia Iranica. Cahier 41, Paris 2009.

Braun O., Zwei Synoden des Katholikos Timotheos I, „Oriens Christianus” 2 (1902) s. 283311.

Payne R.P., State of mixture, Oakland 2015. 